\title{
Ossification of the
}

Transverse Ligament of the Atlas on CT: Frequency and Associated Findings

\section{$\mathrm{CT}$ 를 이용한 환추횡인대 골화증의 빈도와 연관 소견}

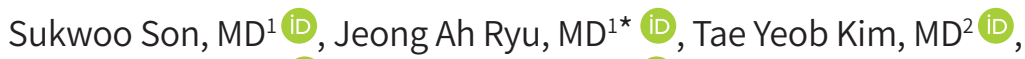
Sungjun Kim, $\mathrm{MD}^{3} \mathbb{D}$, Seunghun Lee, $\mathrm{MD}^{4}$ (D)

Departments of ${ }^{1}$ Radiology, ${ }^{2}$ Internal Medicine, Hanyang University College of Medicine, Guri Hospital, Guri, Korea

${ }^{3}$ Department of Radiology, Yonsei University School of Medicine, Gangnam Severance Hospital, Seoul, Korea

${ }^{4}$ Department of Radiology, Hanyang University College of Medicine, Seoul Hospital, Seoul, Korea

Purpose To determine the frequency of ossification of the transverse ligament of the atlas (OTLA) and to investigate the associated findings on cervical spine CT and plain radiography. Materials and Methods We reviewed 5201 CT scans of the cervical spine of 3975 consecutive patients over an 11-year period for the presence of OTLA and compared them with those of ageand sex-matched controls. The frequency and associated findings of OTLA were investigated and statistically correlated.

Results The overall frequency of OTLA was 1.1\% (45 of 3975 patients) and increased with age ( $p<$ 0.005). The frequency of OTLA in patients over 80 years was $12 \%$. The space available for the spinal cord (SAC) was smaller in patients with OTLA $(p<0.005)$. Mineralization of the complex of the anterior atlantooccipital membrane and Barkow ligament, ossification of the ligamentum flavum, and kyphosis of the cervical spine positively correlated to the presence of OTLA ( $p<$ 0.005).

Conclusion OTLA was associated with age, SAC narrowing, cervical kyphosis, and ossification of other cervical ligaments and may be associated with degenerative spondylosis, systemic hyperostotic status, or mechanical stress or instability.

Index terms Multidetector Computed Tomography; Spine; Ligaments

\section{서론}

환추횡인대골화증(ossification of the transverse ligament of the atlas; 이하 OTLA)은

Received March 16, 2019

Revised June 3, 2019

Accepted September 5, 2019

*Corresponding author Jeong Ah Ryu, MD Department of Radiology, Hanyang University College of Medicine, Guri Hospital, 153 Gyeongchun-ro, Guri 11923, Korea.

Tel 82-31-560-2449

Fax 82-31-560-2551

E-mail ryuja@hanyang.ac.kr

This is an Open Access article distributed under the terms of the Creative Commons Attribution Non-Commercial License (https://creativecommons.org/ licenses/by-nc/4.0) which permits unrestricted non-commercial use, distribution, and reproduction in any medium, provided the original work is properly cited.

ORCID iDs

Sukwoo Son (1D

https://

orcid.org/0000-0002-4164-1352

Jeong Ah Ryu (D)

https://

orcid.org/0000-0002-4474-180X

Tae Yeob Kim (D)

https://

orcid.org/0000-0001-7978-5303

Sungjun Kim (D)

https://

orcid.org/0000-0002-7876-7901

Seunghun Lee (D)

https://

orcid.org/0000-0002-4348-7993 
1978년도에 처음 보고된 매우 드문 소견으로(1-3), 두개경부접합부 척수병증(myelopathy at the craniocervical junction) (4), 환추 저형성증(atlas hypoplasia) (5), 축추 치돌기 과형성증(dens hypertrophy) (6), 환추-축추 탈구(atlanto-axial dislocation) (7), 류마티스 관절염(rheumatoid arthritis) (8), 불소증(fluorosis) (9) 등과 연관성이 있다고 보고된 바 있다.

환추횡인대골화증이나 석회화증은 연골석회증(chondrocalcinosis) $(10,11)$ 뿐만 아니라 crowned dens syndrome (12) 과의 연관성도 보고되어 있으며, 최근 연구에 의하면(13), 환추-축추의 칼슘피 로인산 결정(calcium pyrophosphate dehydrate; 이하 CPPD) 침착, 나이, 역치상 돌기의 연부조 직 비후(retro-odontoid soft tissue thickening)와도 양의 상관관계가 있는 것으로 보고되어 있다.

OTLA는 비정상적인 척추의 이동성과 불안정성과 연관이 있다고 일부 여겨지며, 기계적 스트레 스와 척추 불균형이 이에 중요한 역할을 할 것으로 생각된다(14, 15). OTLA는 척수병증이나 환추 축추 불안정성, 연골 석회화가 없는 경우에도 동반된 경우가 발견되며 후종인대골화증(ossification of the posterior longitudinal ligament; 이하 OPLL)이나 황색인대골화증(ossification of the ligamentum flavum; 이하 OLF)과 같이 크기가 커서 척추병증을 유발한 경우에만 감압이 필요한 양 성 퇴행성 변화로 볼 수도 있다(16).

본 연구에서는 경추 전산화단층촬영(cervical spine CT; 이하 C-spine CT)을 이용하여 OTLA의 발생 빈도와 이에 동반된 소견들을 분석하였다.

\section{대상과방법}

본 연구는 후향적으로 진행되었으며 본원의 IRB 심의위원회를 통과하였고 사전 동의는 면제되었 다(IRB No. 2014-10-015). 2003년 1월부터 2014년 10월까지 본원을 내원한 환자들 중 두통, 외상 등 의 여러 가지 이유로 시행된 C-spine CT를 분석하여 OTLA가 동반된 경우를 분류하였다. 이들 중 환추에 선천성 기형이나 골절, 후천성 교착(ankylosis) 등으로 인해 환추횡인대나 주변 구조물의 측 정이 불가한 경우를 제외하였다. 이후 전산의무기록을 분석하여 최근 5년간 두통과 경도 외상으로 응급실에 방문하여 C-spine CT를 촬영한 환자 중, 경추에 급성 병변이 관찰되지 않고 귀가한 환자 를 대상으로 연령과 성별을 일치하여 OTLA 환자군의 5배수 대조군을 설정하여 OTLA와 동반된 소 견들의 통계학적 유의성을 분석하였다. 이들 또한 마찬가지로 환추에 선천성 기형이나 골절, 후천성 교착(ankylosis) 등으로 인해 환추횡인대나 주변 구조물의 측정이 불가한 경우는 포함시키지 않았다.

\section{영상 획득}

C-spine CT는 사대(clivus)에서부터 제3흥추까지를 포함하였으며 프로토콜은 다음과 같다: 120 $\mathrm{kVp}$, 자동관전류변조(automatic tube current modulation, 최대 $330 \mathrm{~mA}$ ), 절편 두께 0.75 2.00 $\mathrm{mm}$. 축면영상은 근원 영상(source images)으로부터 1-, $3 \mathrm{~mm}$ 두께로 생성하였으며, 시상면과 관 상면영상 또한 2-, $3 \mathrm{~mm}$ 두께로 생성하였다. 병원 방침에 따라 경추일반촬영(후전면, 측면 촬영)과 흉부일반촬영을 함께 시행하였다. 모든 영상은 의료영상정보시스템(Picture Archiving and Communication System)으로 전송하여 저장되었다. 


\section{영상 분석과 측정}

C-spine CT는 12 년 경력의 두 명의 근골격계 영상의학과 전문의가 후향적으로 합의하에 분석하 였다. OTLA의 CT 소견은 뼈를 보는 방식(bone algorithm)을 기반으로 분석하였으며 이산적 결절 형(discrete nodular), 선형(linear) 혹은 곡선형(curvilinear)의 $180 \mathrm{HU}$ 이상의 고음영이 지방 음 영의 유무와 상관없이 환추횡인대에 존재하는 것으로 정의하였다(Fig. 1A) $(4-6,17)$. 또한 중앙시상 면 영상에서 전상 환추의 내측 최대 전후 길이[inner anteroposterior (이하 $\mathrm{AP}$ ) diameter of the atlas], 치상돌기(odontoid process)의 전후 길이(AP diameter), 척수 공간(space available for spinal cord; 이하 SAC)을 측정하였다. SAC는 연부조직을 보는 방식(soft tissue algorithm)에서, 환추 의 중앙시상면에서 cerebrospinal fluid (이하 CSF) column의 지름으로 정의하였다(Fig. 1B, C) (18).

치첨인대(apical ligament of dens), 익인대(alar ligament), 전방환추후두막-Barkow 인대 복합 체(anterior atlantooccipital membrane - Barkow ligament complex; 이하 AAOM-BLC)의 광 물질침착(mineralization), 황색인대골화증, 후종인대골화증은 축면, 시상면 영상에서 평가하였다. 인대의 광물질침착(mineralization) 소견은 비후 여부와 관계없이 광화의 유무로 각각 분류하였다. 미만성특발성골격뼈과다증(diffuse idiopathic skeletal hyperostosis; 이하 DISH)은 동반된 분절 의 개수에 따라 평가하였으며 이에 따라 ‘없음' ' 1 2 분절', ‘3개 이상의 분절’로 분류하였다.

경추후만증(cervical kyphosis)과 측만증(scoliosis)는 C-spine CT와 일반촬영으로 평가하였으 며 15도 이상 기울어졌을 경우 ‘있음', 그렇지 않을 경우 ‘없음’으로 분류하였다. 추간강 협착(disc space narrowing)은 추간강의 높이가 정상의 절반 이하로 감소하였을 때로 정의하였으며 그 분절 수를 확인하여 ‘없음, ' 1 2분절, ‘3개 이상의 분절’로 분류하였다. 환추축추 골관절염(atlanto-axial osteoarthritis), 아탈구(subluxation)나 탈구(dislocation), 경추의 기형(C-spine anomaly) 유무 또 한 C-spine CT와 일반촬영으로 평가하였다. 류마티스 관절염의 유무는 전자의무기록과 C-spine CT, 일반촬영을 통해 평가하였으며, 대동맥궁광화(aortic arch mineralization) 소견은 흥부일반

Fig. 1. Method of the measurement of diameters of the dens, atlas, and space available for the SAC on midsagittal CT images.

A. OTLA is defined on the axial CT bone algorithm image. Discrete nodular, linear, or curvilinear hyper-attenuated mineralization within the transverse ligament, with a high attenuation of $180 \mathrm{HU}$, with or without a central fatty area (arrows), is determined as OTLA.

B. On the CT bone algorithm mid-sagittal image, the distance from the posterior cortical border of the anterior arch of the atlas to the anterior cortical border of the posterior arch of the atlas is measured as the AP diameter of the atlas (dotted line between white arrowheads). On the mid-sagittal image, the distance from the anterior cortical border to the posterior cortical border is measured as the AP diameter of the dens (solid line between the black arrowheads).

C. On the CT soft-tissue algorithm mid-sagittal image, SAC is defined as the sagittal diameter of the cerebrospinal fluid column at the C1 level (dotted line between white arrowheads). The transverse ligament (black arrows), apical ligament (arrowheads), and tectorial membrane and cruciate ligament (white arrows) of the atlas are clearly delineated.

$\mathrm{AP}=$ anteroposterior, OTLA = ossification of the transverse ligament of the atlas, $\mathrm{SAC}=$ space available for spinal cord
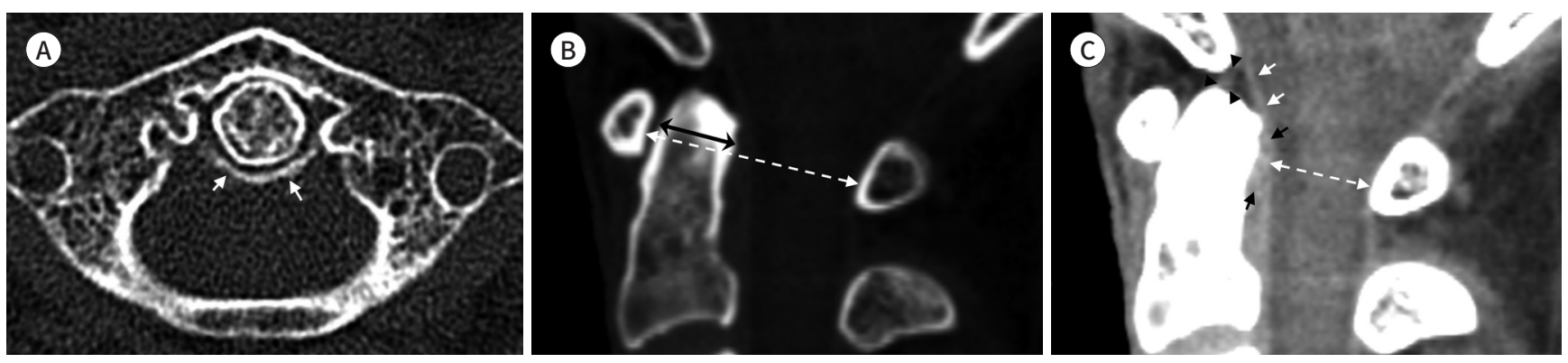
촬영을 이용하여 4가지 단계로 분류하였다(19).

\section{분석과 통계}

OTLA의 빈도는 나이와 성별에 따라 정리하였다(Table 1). 대상군과 대조군과의 차이를 확인하기 위해 연속변수(나이, 환추, 축추의 전후 길이와 $\mathrm{SAC}$ )는 student $t$-test를, 범주형 변수(성별, 치첨인 대, 익인대, AAOM-BLC의 광화, OPLL, OLF, DISH, 경추측만증과 후만증, 환추-축추의 골관절염, 아탈구, 탈구 소견, 류마티스 관절염, 경추 척추 기형, 대동맥궁광화)는 Pearson chi-square test과 Fisher's exact test를 시행하였다(Table 2). 범주형 변수들의 교차비(odds ratio; 이하 OR)와 95\% 신 뢰구간(confidence interval)를 비교하였으며, 다변량회귀분석(multivariate logistic regression analyses)을 이용하여 OTLA 유의한 연관관계가 있는 요인을 평가하였다. $p$ value $<0.05$ 의 경우 를 통계학적인 유의성이 있는 것으로 간주하였으며 통계 분석은 SPSS version 21.0 for windows (IBM Corp., Armonk, NY, USA)와 MedCalc 13.1.1 (MedCalc, Ostent, Belgium)을 이용하였다.

\section{결과}

\section{OTLA의 빈도}

총 3975명의 대상에게서 촬영한 5201개의 C-spine CT를 분석하였다. 남성은 2552명으로 나이는 1 103세(평균 $50.7 \pm 17.1$ 세)였으며, 여성은 1423 명으로 1 89세(평균 $57.1 \pm 18.2$ 세)였다. 총 47명 에게서 OTLA 소견이 확인되었으며 그중 한 53세 남성 환자는 30년간의 강직성척추염으로 전체 두 개-경부 인대(craniocervical ligaments)와 치상돌기가 완전히 융합되어 환추횡인대가 구분되지 않아 제외하였고 또 다른 57세 여성 환자의 경우 환추 융합기형으로 환추후궁에 큰 결손이 있어 환 추의 전후 길이와 SAC를 측정할 수 없어 제외되었다. 최종 45명의 OTLA 환자들이 연구에 포함되었 고 이들의 평균 나이는 $71.7 \pm 10.8$ 세였다(남성 20명, 53 94세, 평균 $68.5 \pm 12.0$ 세; 여성 25명,

Table 1. Demographic Characteristics of Patients

\begin{tabular}{cccccc}
\hline $\begin{array}{c}\text { Age, } \\
\text { years }\end{array}$ & $\begin{array}{c}\text { Total, } \\
\text { number }\end{array}$ & $\begin{array}{c}\text { Male, } \\
\text { number }\end{array}$ & $\begin{array}{c}\text { Female, } \\
\text { number }\end{array}$ & $\begin{array}{c}\text { OTLA, } \\
\text { number }\end{array}$ & $\begin{array}{c}\text { Frequency } \\
\text { of OTLA, \% }\end{array}$ \\
\hline$<10$ & 77 & 51 & 26 & 0 & 0 \\
$10-19$ & 216 & 164 & 52 & 0 & 0 \\
$20-29$ & 417 & 289 & 128 & 0 & 0 \\
$30-39$ & 566 & 401 & 165 & 0 & 0 \\
$40-49$ & 828 & 540 & 288 & 0 & 0 \\
$50-59$ & 897 & $558(5)$ & $339(2)$ & 7 & 0.8 \\
$60-69$ & 545 & $322(8)$ & $223(4)$ & 12 & 2.2 \\
$70-79$ & 346 & $192(3)$ & $154(13)$ & 16 & 4.6 \\
$\geq 80$ & 83 & $35(4)$ & $48(6)$ & 10 & 12.0 \\
\hline Total & 3975 & $2552(20)$ & $1423(25)$ & 45 & $1.1(0.8 / 1.8)^{*}$ \\
\hline
\end{tabular}

Numbers in parentheses are patients with OTLA.

*Numbers in parentheses are percentages of male/female patients with OTLA.

OTLA = ossification of the transverse ligament of the atlas 
Table 2. Frequencies of the Associated Findings in 270 Patients with or without OTLA

\begin{tabular}{|c|c|c|c|}
\hline Associate Findings & No OTLA $(n=225)$ & OTLA $(n=45)$ & $p$-Value \\
\hline Atlas $\mathrm{AP}^{*}$ & $29.6 \pm 2.17$ & $29.0 \pm 2.12$ & 0.098 \\
\hline Dens AP* & $11.5 \pm 0.95$ & $11.3 \pm 1.03$ & 0.259 \\
\hline $\mathrm{SAC}^{*}$ & $13.6 \pm 1.74$ & $12.7 \pm 1.77$ & 0.003 \\
\hline Apical ligament mineralization ${ }^{\dagger}$ & $174 / 51(77.3 / 22.7)$ & $38 / 7(84.4 / 15.6)$ & 0.289 \\
\hline Alar ligament mineralization ${ }^{\dagger}$ & 192/33 (85.3/14.7) & $39 / 6(86.7 / 13.3)$ & 0.816 \\
\hline 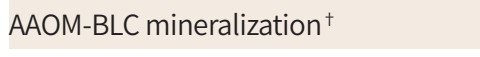 & $150 / 74(67.0 / 33.0)$ & $20 / 25(44.4 / 55.6)$ & 0.004 \\
\hline Cervical OLF ${ }^{\dagger}$ & 204/21 (90.7/9.3) & $31 / 14(68.9 / 31.1)$ & $<0.001$ \\
\hline Cervical OPLL ${ }^{\ddagger}$ & $147 / 51 / 27(65.3 / 22.7 / 12.0)$ & $26 / 10 / 9(57.8 / 22.2 / 20.0)$ & 0.343 \\
\hline Cervical DISH ${ }^{\ddagger}$ & 210/3/12 (93.3/1.3/5.3) & $39 / 2 / 4(86.7 / 4.4 / 8.9)$ & 0.230 \\
\hline Cervical kyphosis $^{\dagger}$ & $166 / 59(73.8 / 26.2)$ & $23 / 22(51.1 / 48.9)$ & 0.002 \\
\hline Cervical scoliosis $^{\dagger}$ & $162 / 63(72.0 / 28.0)$ & $35 / 10(77.8 / 22.2)$ & 0.426 \\
\hline Disc space narrowing ${ }^{\ddagger}$ & $126 / 84 / 15(56.0 / 37.3 / 6.7)$ & $19 / 19 / 7(42.2 / 42.2 / 15.6)$ & 0.074 \\
\hline AA osteoarth ritis $^{\dagger}$ & $110 / 115(48.9 / 51.1)$ & $26 / 19(57.8 / 42.2)$ & 0.276 \\
\hline 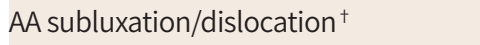 & 206/19 (91.6/8.4) & $43 / 2(95.6 / 4.4)$ & 0.544 \\
\hline Cervical vertebral anomaly, $n$ & $6(2.7)$ & $2(4.4)$ & 0.624 \\
\hline Rheumatoid arthritis, $n$ & $3(1.3)$ & $1(2.2)$ & 0.520 \\
\hline Aortic arch mineralization $(0 / 1 / 2 / 3), n$ & $106 / 22 / 29 / 68(47.1 / 9.8 / 12.9 / 30.2)$ & $19 / 5 / 12 / 9(42.2 / 11.1 / 26.7 / 20.0)$ & 0.097 \\
\hline
\end{tabular}

Numbers in parentheses are percentages.

*Mean \pm standard deviation, $\mathrm{mm}$.

${ }^{\dagger}$ Not seen/seen, $n$.

${ }^{\ddagger}$ Not seen $/ 1-2$ levels/ $\geq 3$ levels, $n$.

$\mathrm{AA}=$ atlanto-axial, $\mathrm{AAOM}-\mathrm{BLC}=$ anterior atlantooccipital membrane - Barkow ligament complex, $\mathrm{AP}=$ anteroposterior, $\mathrm{DISH}=$ diffuse idiopathic skeletal hyperostosis, OLF = ossification of the ligamentum flavum, OPLL = ossification of the posterior longitudinal ligament, OTLA = ossification of the transverse ligament of the atlas, SAC = space available for spinal cord

53 89세, 평균 $74.3 \pm$ 9.1세) (Table 1). OTLA의 전체 빈도는 3975명 중 45명으로 1.1\%였다. 50세 미만의 환자 중 OTLA 소견을 보인 경우는 없었다. 50세 이상의 환자들 중 OTLA의 빈도는 $2.4 \%$ (1871명 중 45 명)였으며 80 세 이상의 경우 $12 \%(83$ 명 중 10 명)였다. OTLA의 빈도는 나이에 따라 증 가하는 양상을 보였다 $(p<0.001$, univariate logistic regression analysis) (Table 1). 환자군 내의 남성과 여성의 평균 나이는 유의하게 다르지 않았다 $(p=0.210$, independent $t$-test). 남성에서 OTLA 의 빈도는 $0.8 \%(2552$ 명 중 20명), 여성은 $1.8 \%$ (1423명 중 25명)였으며(Table 1), OTLA의 유무는 성 별과 유의한 상관관계가 없었다( $p=0.355$, Pearson chi-square test).

\section{동반된 소견}

환추 전후 길이의 평균값은 OTLA 환자군에서 $29.0 \pm 2.12 \mathrm{~mm}$ (범위, $25.0 ~ 33.5 \mathrm{~mm}$ ), 대조군에 서 $29.6 \pm 2.17 \mathrm{~mm}$ (범위, 25.1 37.0 mm)로 확인되었으며 통계적 유의성은 관찰되지 않았다 $(p=$ 0.098, independent $t$-test). 환추의 전후 길이는 대조군에서 나이에 따라 조금씩 감소하는 경향을 보이고(Fig. 2A), 그 범위는 OTLA 환자군에서 더 작게 관찰되었으나(Fig. $3 \mathrm{~A})$ 통계적으로 유의하지 않았다. 축추 치돌기 전후 길이의 평균값은 OTLA 환자군에서 $11.3 \pm 1.03 \mathrm{~mm}$ (범위, 8.9 12.9 $\mathrm{mm}$ ), 대조군에서 $11.5 \pm 0.95 \mathrm{~mm}$ (범위, 9.5 14.1 mm)로 측정되었으며 통계적 유의성은 관찰되 

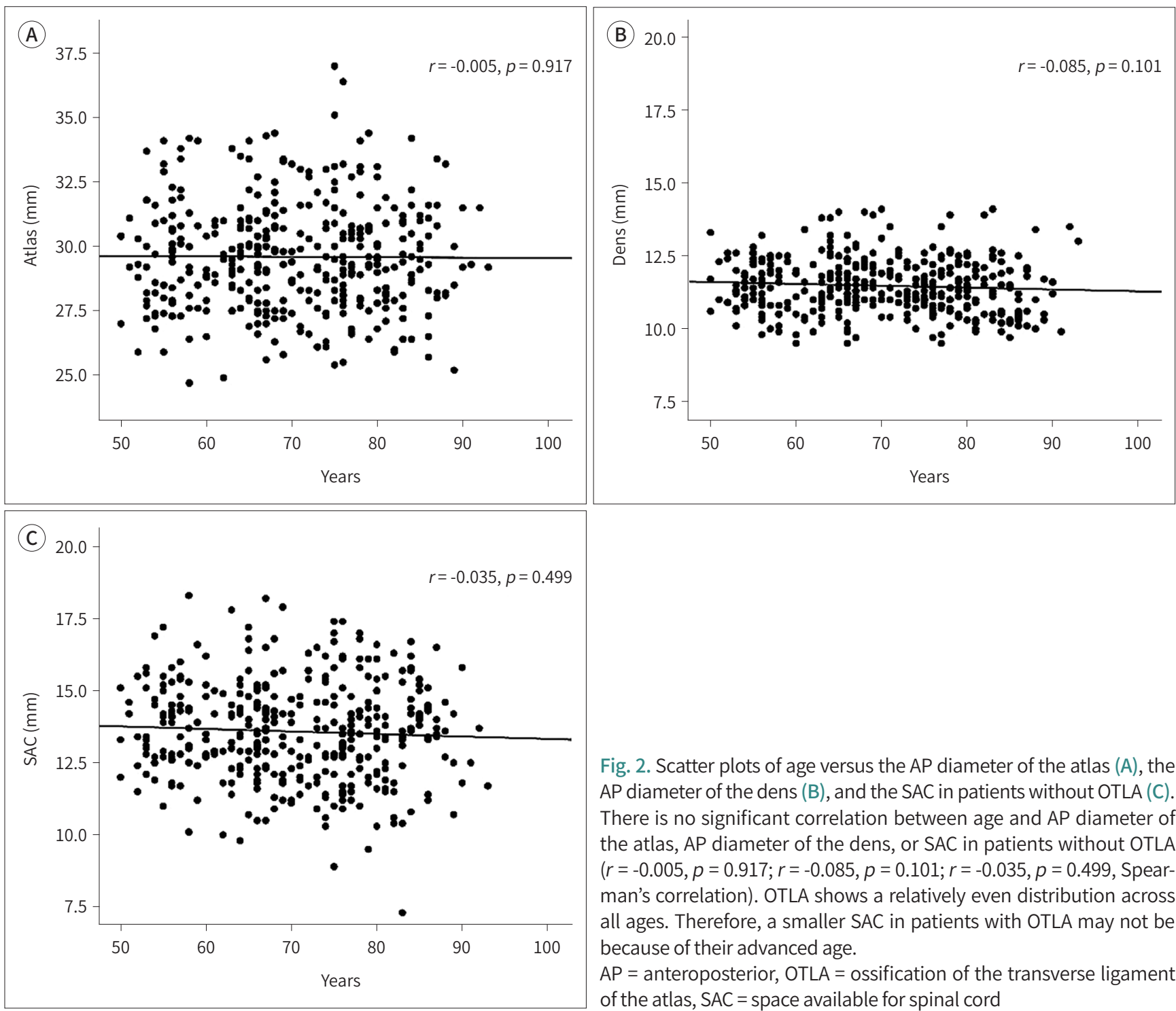

Fig. 2. Scatter plots of age versus the AP diameter of the atlas (A), the AP diameter of the dens (B), and the SAC in patients without OTLA (C). There is no significant correlation between age and AP diameter of the atlas, AP diameter of the dens, or SAC in patients without OTLA $(r=-0.005, p=0.917 ; r=-0.085, p=0.101 ; r=-0.035, p=0.499$, Spearman's correlation). OTLA shows a relatively even distribution across all ages. Therefore, a smaller SAC in patients with OTLA may not be because of their advanced age.

$\mathrm{AP}=$ anteroposterior, OTLA = ossification of the transverse ligament of the atlas, $\mathrm{SAC}=$ space available for spinal cord

지 않았다 $(p=0.259$, independent t-test) (Figs. 2B, 3B).

$\mathrm{SAC}$ 의 평균값은 OTLA 환자군에서 $12.7 \pm 1.77 \mathrm{~mm}$ (범위, 9.3 16.5 mm), 대조군에서 $13.6 \pm$ $1.74 \mathrm{~mm}$ (범위, 9.5 18.2 mm)로 측정되었고 두 군의 차이는 통계적으로 유의성을 보였다 $(p=$ 0.003, independent t-test) (Fig. 2C).

AAOM-BLC의 광물질침착과 황색인대의 골화 소견은 OTLA와 의미 있는 양의 상관관계를 보였 다 $(p=0.004$ and $p<0.001$, Pearson chi-square test) (Table 2). 그러나 치첨인대나 익인대의 광 물질침착(각각 $p=0.289, p=0.816), \mathrm{OPLL}(p=0.343), \mathrm{DISH}(p=0.230)$ 는 OTLA와 유의한 상관관 계를 보이지 않았다. 경추후만증의 경우 OTLA와 유의한 상관관계를 보였으나 $(p=0.002$, Pearson chi-square test), 경추측만증과 OTLA와의 관계는 통계적으로 유의하지 않았다( $p=0.426)$.

추간강 협착 $(p=0.074)$, 환추축추 골관절염 $(p=0.276)$, 환추-축추 아탈구나 탈구( $p=0.544)$, 경 추기형 $(p=0.624)$, 류마티스 관절염 $(p=0.520)$, 대동맥궁광화 $(p=0.097)$ 소견 모두 OTLA와 유의 
Fig. 3. Box Plots of the AP diameter of the atlas (A), the AP diameter of the dens (B), and the SAC in patients with or without OTLA (C). $A, B$. The average AP diameters of the atlas and dens are not significantly different between the patients with and those without OTLA ( $p=$ $0.098, p=0.259$, independent $t$-test).

C. The average SAC is significantly smaller in the OTLA group than in the control group $(p=0.003)$. In the control group, SAC shows a wide normal range.

$\mathrm{AP}=$ anteroposterior, $\mathrm{OTLA}=$ ossification of the transverse ligament of the atlas, $\mathrm{SAC}=$ space available for spinal cord
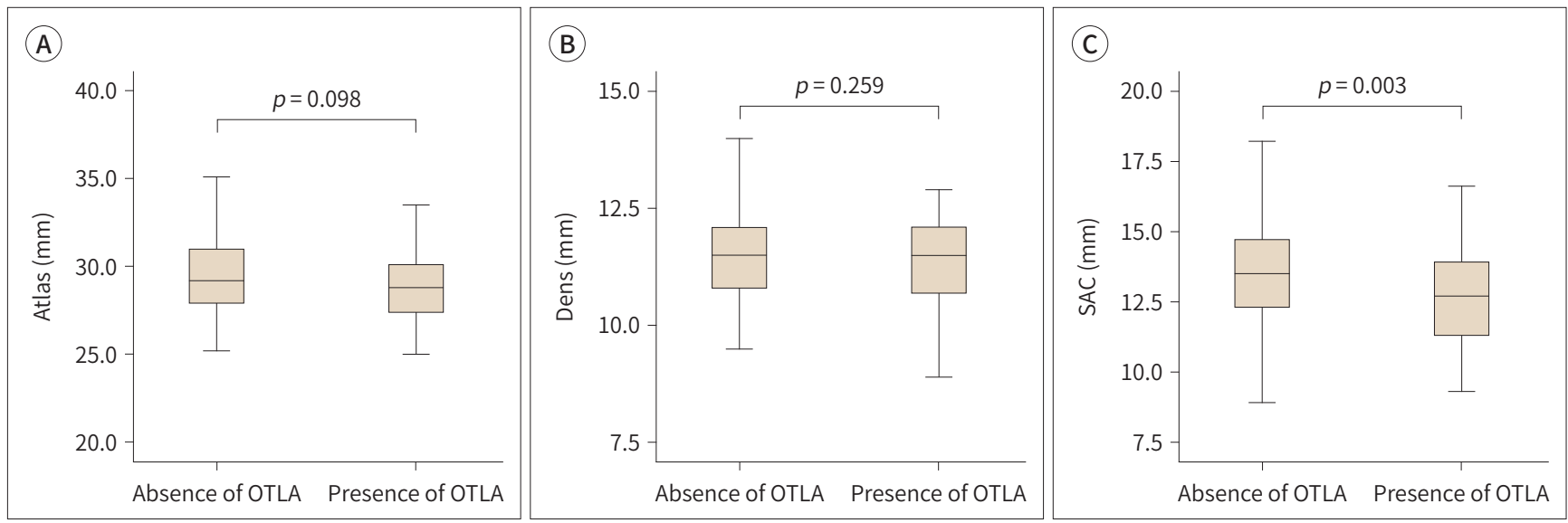

Table 3. Multivariate Logistic Analysis of OTLA and Associated Findings

\begin{tabular}{lccc}
\hline & OR & $95 \% \mathrm{Cl}$ & $p$-Value \\
\hline Age, years & 0.977 & $0.942-1.014$ & 0.214 \\
Sex, male & 1.286 & $0.594-2.786$ & 0.523 \\
SAC, mm & 0.745 & $0.604-0.920$ & 0.006 \\
Presence of AAOM-BLC mineralization & 2.615 & $1.267-5.397$ & 0.009 \\
Presence of cervical OLF & 4.419 & $1.841-10.606$ & 0.001 \\
Presence of cervical kyphosis & 2.351 & $1.136-4.869$ & 0.021 \\
\hline
\end{tabular}

AAOM-BLC = anterior atlantooccipital membrane - Barkow ligament complex, $\mathrm{Cl}=$ confidence interval, OLF = ossification of the ligamentum flavum, $\mathrm{OR}=$ odds ratio, OTLA = ossification of the transverse ligament of the atlas, SAC = space available for spinal cord

한 연관성은 없었다(Pearson chi-square test). 그러나 OTLA와 동반된 환추축추 아탈구나 류마티 스 관절염 환자는 그 수가 매우 적었다(각각 $n=2, n=1)$ (Table 2).

C-spine CT에서 경추 $\mathrm{OLF}(\mathrm{OR}=4.419)$ 의 유무와 $\mathrm{AAOM}-\mathrm{BLC}$ 의 광물질침착 $(\mathrm{OR}=2.615)$, 경추 후만증 $(\mathrm{OR}=2.351)$ 소견의 유무는 모두 OTLA와 양의 연관관계가 있는 것으로 나타났다. SAC의 경 우 OTLA환자군에서 유의하게 작았다(OR=0.745) (Table 3$)$.

고찰

환추횡인대는 두개-경추의 인대 중 가장 크고 강한 인대이다(20). 이는 환추의 전방 탈구를 일차적 으로 방지하는 중요한 구조물이며 상대적으로 탄성도가 떨어져 하중에 약하다(21).

척추인대의 골화는 유전적, 환경적 요인과 호르몬의 상호작용 등 다양한 원인에 의해 발생한다 (22). 골화와 석회화의 영상의학적 구분은 어려우며(5) 연속선상에 있는 소견으로 생각된다(23-25). 
그러나 기존 연구에서는 환추횡인대의 골화와 석회화가 각각 구분되어 보고되어 있는데, 환추횡인 대의 골화는 외상 후 상태나 환추, 축추치돌기의 저형성증과 같은 발생 이상과 동반된 매우 드문 경 추 척수병증(cervical myelopathy) (4-7)으로, 환추횡인대의 석회화는 CPPD 결정 침착과 연관된 소견으로 더 빈번하게 발생하는 것으로 보고되어 있다. 환추횡인대의 석회화 소견이 심한 경부 통 증과 동반될 경우 Crowned dens 증후군으로 볼 수 있다(10-13).

기존에 발표되었던 한 사후 연구에서 OTLA의 유병률은 $0.1 \%$ 미만으로 보고된 바 있으나(1) 본 연구에서는 $1.1 \%$ 로 더 높게 나타났다. 이는 OTLA의 유무를 평가하는 방법으로 사용된 C-spine CT 가 골화를 평가하는데 있어 사체보다 더 쉽기 때문으로 생각된다.

Anno 등(26)은 최근 건강한 1136명의 C-spine CT를 이용하여 환추횡인대 석회화의 유병률을 분석하였고 이는 약 $3.5 \%$ 로 나타났다. 이는 본 연구에서 OTLA의 유병률(1.1\%)보다 높은 결과이지 만 본 연구에서는 모든 연령을 대상으로 한 반면, 해당 연구에서는 대상군을 40세 이상으로 설정하 였고 본 연구에서는 OTLA 유무의 기준을 $180 \mathrm{HU}$ 로 설정하였으나 해당 연구에서는 이보다 낮은 환 추횡인대 고음영 소견 또한 양성으로 간주하였기 때문으로 생각된다. 하지만 해당 연구에서의 환추 횡인대 석회화의 유병률은 본 연구에서의 OTLA와 마찬가지로 나이가 증가함에 있어 그 빈도가 증 가하는 소견을 보였다. 또한 본 연구에서 50세 미만의 환자는 OTLA가 발견되지 않았고 오직 50세 이상의 환자들에게서만 발견이 되었는데, Anno 등(26)의 연구에서도 $99.2 \%$ 의 환추횡인대 석회화 가 50 세 이상에서 발견되었으며 이를 통해 OTLA나 환추횡인대 석회화가 퇴행성 변화와도 관련이 있을 것으로 생각해볼 수 있다.

본 연구에서 환추의 저형성증은 환추 후궁이 작지만 온전한 경우로 정의하였으며 Currarino 분 류에서처럼 후궁의 융합 기형이 있을 경우는 제외하였다(27). 한 최근 연구에서는 환추 저형성증의 기준으로 $26 \mathrm{~mm}$ 를 제시하였다(28). 본 연구에서 OTLA 환자군의 환추 전후 길이는 대조군에 비해 그 범위와 평균값이 작은 양상을 보였으나 통계적으로 유의하지는 않았다(Fig. 3A). 축추 치돌기의 전후길이 또한 같은 양상을 보였으며(Fig. 3B) 이는 기존의 증례 보고와 다른 결과이다(6).

$\mathrm{SAC}$ 는 척수와 CSF로 이루어진 공간이며(29) 환추, 축추 치돌기, 횡인대, 덮개막(tentorial membrane), 경막(dura mater), 환추-축추 후방막(posterior atlantoaxial membrane) 전방, 후방 경막 외공간(epidural space)에 의해 결정된다(30). 따라서 횡인대의 비후, 환추 저형성증, 축추 치돌기 과형성증, 덮개막 비후와 같은 이상 소견들은 SAC에 직접적으로 영향을 미친다. 본 연구에서는 $\mathrm{OTLA}$ 환자군에서 유의하게 작은 SAC이 확인되었다 $(p=0.003)$. 기존 연구에 의하면 일반촬영에서 비정상 SAC의 기준은 $14 \mathrm{~mm}$ 였으며(29) 척수병증 환자군을 대상으로 측정한 평균값은 $11.1 \mathrm{~mm}$ 였다(30).

전방환추후두막과 Barkow 인대는 정 중앙에서 만나 융합되며 기능적으로 협동 관계에 있다(31). 즉 AAOM-BLC는 횡인대를 지지하는 역할을 한다(20,31). 전방환추후두막과 Barkow 인대는 정 중 앙부에 광화 소견이 동반될 경우 C-spine CT에서는 둘 중 어느 구조물의 소견인지 명확히 구분되지 않을 수 있다. AAOM-BLC의 광화는 OTLA와 유의한 연관관계를 보였고 $(p=0.004)$ 두 구조물 간의 협동 작용과 관계가 있을 것으로 생각된다.

OLF는 경추에서 매우 드물게 나타나고, 그 빈도는 $0.9 \%$ 로 보고되어 있다(32, 33). 경추 OLF는 
OPLL과 매우 밀접한 관계가 있고 척추인대의 골화를 촉진시키는 전신적인 골 과잉증(systemic hyperostosis) 이나(32, 33), 호르몬, 성장 인자와 같은 조직 인자들의 상향 조절(upregulation)과 관 련이 있는 것으로 보고된 바 있다(22). 본 연구에서 경추 OLF는 OTLA 환자군에서 유의하게 빈도가 높게 확인되었고 $(p<0.001)$ 이를 통해 두 인대의 골화에 공통된 병인이 존재하는 것으로 생각할 수 있다.

기계적 스트레스는 척추인대 세포의 뼈 발생적 분화(osteogenic differentiation)를 유도하는데 중요한 역할을 하는 것으로 생각되어 왔다(14). 경추후만증의 경우 척추인대 골화의 발생에 영향을 주는 것으로 제안된 바 있고(14), 다른 기존 연구에서도 경추후만증과 경추 OLF와의 연관관계가 보 고되었다(33). 본 연구에서도 OTLA와 경추후만증과의 유의한 연관관계를 확인할 수 있었다.

본 연구에는 몇 가지 제한점이 있다. 첫째, 본 연구는 본원에 내원하여 C-spine CT를 촬영한 환자 를 대상으로 진행하였기 때문에 전체 인구 집단의 특성을 반영하지 않는다. 둘째, 환추횡인대의 석 회화에 대해 조사하지 않았다. 셋째, 경추 척수병증이나 인대 변성과 같은 MRI 소견과의 연관성을 확인하지 않았다. 마지막으로, 본 연구에서 OTLA와의 통계적 유의성이 확인된 연관된 동반 소견 간 의 관계를 설명하지 못하였다.

본 연구를 통해, OTLA는 전체 대상 군의 $1.1 \%$ 에서 관찰되는 드문 소견이며 나이에 따라 증가하 는 양상을 보이는 것을 알 수 있었다. OTLA와 연관된 소견으로는 SAC 감소, AAOM-BLC 광화, 경 추 OLF, 경추후만증이 있으며 이는 퇴행성 척추병증, 전신적인 골 과잉 상태, 혹은 기계적 스트레스 나 불안정성에 의한 것으로 생각된다.

\section{Author Contributions}

Conceptualization, R.J.A., data curation, S.S., R.J.A., K.T.Y.; formal analysis, S.S., K.T.Y.; investigation, S.S.; methodology, R.J.A., K.T.Y.; project administration, R.J.A., K.S.; resources, R.J.A.; software, S.S., K.T.Y.; suprvision, R.J.A.; validation, S.S.; visualization, S.S., R.J.A., K.T.Y.; writing-original draft, S.S., R.J.A.; and writing-review \& editing, S.S., R.J.A., K.S., L.S.

\section{Conflicts of Interest}

The authors have no potential conflicts of interest to disclose.

\section{REFERENCES}

1. Resnick D, Pineda C. Vertebral involvement in calcium pyrophosphate dihydrate crystal deposition disease. Radiographic-pathological correlation. Radiology 1984;153:55-60

2. Wackenheim A. Ossification of the transverse ligament. Two observations (author's transl). J Radiol Electrol Med Nucl 1978;59:413-414

3. Dietemann JL, Metzger JM, Bonneville JF, Wackenheim A. Ossification of the transverse ligament of the atlas. A report on three new cases (author's transl). J Radiol Electrol Med Nucl 1979;60:209-210

4. Perera S, Davis CH, Gupta RC. Spinal cord compression caused by ossification of the transverse ligament of the atlas. Br J Neurosurg 1995;9:787-788

5. Tsuruta W, Yanaka K, Okazaki M, Matsumura A, Nose T. Cervical myelopathy caused by hypoplasia of the atlas and ossification of the transverse ligament--case report. Neurol Med Chir (Tokyo) 2003;43:55-59

6. Tang JG, Hou SX, Shang WL, Wu WW. Cervical myelopathy caused by anomalies at the level of atlas. Spine (Phila Pa 1976) 2010;35:E77-E79

7. Hayashi T, Hirose Y, Sagoh M, Murakami H. Ossification of transverse ligament of the atlas associated with atlanto-axial dislocation--case report. Neurol Med Chir (Tokyo) 1998;38:425-428 
8. De Geyter L, Uyttendaele D, Bosmans I, Van de Velde E. Ossification of the transverse atlantoid ligament in rheumatoid arthritis. Eur Spine J 1993;2:113-114

9. Wang W, Kong L, Zhao H, Jia Z. Ossification of the transverse atlantal ligament associated with fluorosis: a report of two cases and review of the literature. Spine (Phila Pa 1976) 2004;29:E75-E78

10. Roverano S, Ortiz AC, Ceccato F, Paira SO. Calcification of the transverse ligament of the atlas in chondrocalcinosis. J Clin Rheumatol 2010;16:7-9

11. Constantin A, Marin F, Bon E, Fedele M, Lagarrigue B, Bouteiller G. Calcification of the transverse ligament of the atlas in chondrocalcinosis: computed tomography study. Ann Rheum Dis 1996;55:137-139

12. Goto S, Umehara J, Aizawa T, Kokubun S. Crowned dens syndrome. J Bone Joint Surg Am 2007;89:27322736

13. Chang EY, Lim WY, Wolfson T, Gamst AC, Chung CB, Bae WC, et al. Frequency of atlantoaxial calcium pyrophosphate dihydrate deposition at CT. Radiology 2013;269:519-524

14. Xu P, Wang C, He H, Xu G, YeX. Spinal balance failure: a potential cause of spinal ligament ossification. Med Hypotheses 2011;76:908-910

15. Sasaji T, Kawahara C, Matsumoto F. Ossification of transverse ligament of atlas causing cervical myelopathy: a case report and review of the literature. Case Rep Med 2011;2011:238748

16. Chin WS, Oon CL. Ossification of the posterior longitudinal ligament of the spine. Br J Radiol 1979;52:865869

17. Bressler EL, Marn CS, Gore RM, Hendrix RW. Evaluation of ectopic bone by CT. AJR Am J Roentgenol 1987; 148:931-935

18. Ulbrich EJ, Schraner C, Boesch C, Hodler J, Busato A, Anderson SE, et al. Normative MR cervical spinal canal dimensions. Radiology 2014;271:172-182

19. Hashimoto H, lijima K, Hashimoto M, Son BK, Ota H, Ogawa S, et al. Validity and usefulness of aortic arch calcification in chest X-ray. J Atheroscler Thromb 2009;16:256-264

20. Tubbs RS, Hallock JD, Radcliff V, Naftel RP, Mortazavi M, Shoja MM, et al. Ligaments of the craniocervical junction. J Neurosurg Spine 2011;14:697-709

21. Fielding JW, Cochran Gv, Lawsing JF 3rd, Hohl M. Tears of the transverse ligament of the atlas. A clinical and biomechanical study. J Bone Joint Surg Am 1974;56:1683-1691

22. Li H, Jiang LS, Dai LY. Hormones and growth factors in the pathogenesis of spinal ligament ossification. Eur Spine J 2007;16:1075-1084

23. Inoue H, Seichi A, Kimura A, Endo T, Hoshino Y. Multiple-level ossification of the ligamentum flavum in the cervical spine combined with calcification of the cervical ligamentum flavum and posterior atlanto-axial membrane. Eur Spine J 2013;22 Suppl 3:S416-S420

24. Kawaguchi Y, Seki S, Hori T, Kimura T. Characteristics of ossified lesions in the upper cervical spine associated with ossification of the posterior longitudinal ligament in the lower cervical spine. J Bone Joint Surg Am 2008;90:748-753

25. Miyasaka K, Kaneda K, Sato S, Iwasaki Y, Abe S, Takei H, et al. Myelopathy due to ossification or calcification of the ligamentum flavum: radiologic and histologic evaluations. AJNR Am J Neuroradiol 1983;4:629-632

26. Anno M, Oshima Y, Taniguchi Y, Matsubayashi Y, Kato S, Soma K, et al. Prevalence and natural course of transverse ligament of the atlas calcification in asymptomatic healthy individuals. Spine (Phila Pa 1976) 2018;43:E1469-E1473

27. Sabuncuoglu H, Ozdogan S, Karadag D, Kaynak ET. Congenital hypoplasia of the posterior arch of the atlas: case report and extensive review of the literature. Turk Neurosurg 2011;21:97-103

28. Kelly MP, Oshima Y, Yeom JS, Agarwal R, Bajwa NS, Riew KD. Defining hyoplasia of the atlas: a cadaveric study. Spine (Phila Pa 1976) 2014;39:E1243-E1247

29. Grauer JN, Tingstad EM, Rand N, Christie MJ, Hilibrand AS. Predictors of paralysis in the rheumatoid cervical spine in patients undergoing total joint arthroplasty. J Bone Joint Surg Am 2004;86:1420-1424

30. Oda T, Yonenobu K, Fujimura Y, Ishii Y, Nakahara S, Matsunaga S, et al. Diagnostic validity of space available for the spinal cord at $\mathrm{C} 1$ level for cervical myelopathy in patients with rheumatoid arthritis. Spine (Phila Pa 1976) 2009;34:1395-1398

31. Tubbs RS, Dixon J, Loukas M, Shoja MM, Cohen-Gadol AA. Ligament of Barkow of the craniocervical junction: its anatomy and potential clinical and functional significance. J Neurosurg Spine 2010;12:619-622

32. Guo JJ, Luk KD, Karppinen J, Yang H, Cheung KM. Prevalence, distribution, and morphology of ossification 
of the ligamentum flavum: a population study of one thousand seven hundred thirty-six magnetic resonance imaging scans. Spine (Phila Pa 1976) 2010;35:51-56

33. Miyazawa N, Akiyama I. Ossification of the ligamentum flavum of the cervical spine. J Neurosurg Sci 2007; 51:139-144

\section{$\mathrm{CT}$ 를 이용한 환추횡인대 골화증의 빈도와 연관 소견}

손석우 ${ }^{1} \cdot$ 류정아 $^{*} \cdot$ 김태엽 ${ }^{2} \cdot$ 김성준 $^{3} \cdot$ 이승훈 $^{4}$

목적 경추 전산화단층촬영(cervical spine CT; 이하 C-spine CT)과 일반촬영을 이용하여 환 추횡인대골화증(ossification of the transverse ligament of the atlas; 이하 OTLA)과 연관된 영상 소견에 대하여 알아보았다.

대상과 방법 11 년간 3975 명의 환자에게서 촬영한 5201 개의 C-spine CT를 분석하여 OTLA의 유무를 확인하였고, 이를 대조군과 비교하여 그 빈도와 연관된 영상 소견의 통계학적 유의성 을 확인하였다.

결과 3975명 중 45명에서 OTLA가 확인되었다(1.1\%). 그 빈도는 나이에 따라 증가하는 소견 을 보였으며 $(p<0.005), 80$ 세 이상인 환자의 $12 \%$ 에서 관찰되었다. 척수 공간(space available for spinal cord; 이하 SAC)은 OTLA 환자군에서 유의하게 작은 것으로 확인되었으며( $p<$ 0.005), 전방환추후두막(anterior atlantooccipital membrane)-Barkow 인대 복합체의 광물 질침착(mineralization), 황색인대골화증(ossification of ligamentum flavum), 경추후만증 또한 유의미한 양의 상관관계를 보였다 $(p<0.005)$.

결론 OTLA는 환자의 나이, SAC 협소, 경추후만증, 다른 경추인대의 골화증과 연관되어 퇴행 성 척추병증, 전신적인 골 과잉 상태, 혹은 기계적 스트레스나 불안정성에 관련이 있을 것으로 생각된다. 